\title{
都市化の影響を受けた沿岸沖積平野の地下水環境に 及ぼす非定常な涵養機構の影響
}

\author{
友澤 裕介 $*^{* 1} \cdot$ 小野寺 真一 $^{1} \cdot$ 齋藤 光代 ${ }^{2} \cdot$ 竹内 徹 $^{3} \cdot$ 北岡 豪一 ${ }^{4}$

\section{The effect of unsteady recharge process on the groundwater environment in a coastal urbanized alluvial plain}

\author{
Yusuke TOMOZAWA*1, Shin-ichi ONODERA ${ }^{1}$, \\ Mitsuyo SAITO ${ }^{2}$, Tohru TAKEUCHI ${ }^{3}$, and Koichi KITAOKA ${ }^{4}$
}

\begin{abstract}
In this research, we aimed to examine the effect of unsteady recharge process by river water during an extreme rainfall event on a groundwater environment based on 8-year monitoring results of groundwater level, major water quality, and oxygen and hydrogen stable isotopic ratios $\left(\delta^{18} \mathrm{O}\right.$ and $\left.\delta \mathrm{D}\right)$ in Okayama alluvial plain, coastal Seto Inland Sea.

Hydraulic heads in the deeper groundwater with depths of 10-20 m were below the sea level. It suggests groundwater depression by artificial pumping. The main recharge source of groundwater under steady state was estimated to be river water in the upper plain, while it was rainwater and seawater in the lower plain. However, the deeper groundwater indicated extremely low $\delta^{18} \mathrm{O}$ for 2 years in the central plain, and the highest $\mathrm{EC}$ was observed in the lower plain after the maximum flood. These results suggest that an unsteady recharge process by river water in the central plain and seawater intrusion from the tidal river in the lower plain occurred due to the largest hydraulic gradient between river water and the deeper groundwater. Based on the Darcy flux estimated by the hydraulic gradient for a year after the flood, the transport time of flooding river water to the deeper groundwater in the central plain was estimated to be $169-405$ days. This value was similar to the time that has elapsed before the minimum $\delta^{18} \mathrm{O}$ was observed in the deeper groundwater from the flood (300 days). This result supports the unsteady groundwater recharge process by the extreme flood.
\end{abstract}

Key words: alluvial plain, unsteady, groundwater recharge, oxygen and hydrogen stable isotopic ratios

I . はじめに

2015年に国連によって 2030年までに達成すべ き持続可能な開発目標（SDGs）が設定され，全
17 項目のうち6番目に「安全な水とトイレを世界 中に」という目標がたてられた。すなわち，世界 の多くの都市が立地する沿岸沖積平野では，安全 で便利な水資源として使用している地下水につい

1 広島大学大学院先進理工系科学研究科 Graduate School of Advanced Science and Engineering, Hiroshima University

2 岡山大学大学院環境生命科学研究科 Graduate School of Environmental and Life Science, Okayama University

3 株式会社フジタ地質 Fujita Geology Co., Ltd.

4 岡山理科大学 Okayama University of Science

* 責任著者 tomozawa-hu@hiroshima-u.ac.jp 
て，持続的に利用していくことが重要な課題とい える。また, 今後の気候変動や水需要の変化に対 応していくためには, 降水量, 地形, 地質, 人間 活動状況が異なる世界の沖積平野において, 地下 水涵養及び地下水流動過程や利用にともなう地下 水資源の脆弱性を定量的に評価していくことが必 要と考えられる (林ほか, 2007 ; 小野寺・宮越, 2010 ; 谷口，2011など)。

沿岸沖積平野の帯水層は, その堆積構造として 完新世の海面上昇時に堆積した粘土層を含むこと が多く, 浅層地下水 (不圧地下水) の下層に砂礫 層中に存在する被圧地下水を有し，さらにそれ以 前の気候変動にともなう粘土層と砂碩層の互層か らなる複数の帯水層を有することが多い（齋藤・ 三宅，2003；林ほか，2003；三宅・凨藤，2003； 村岡, 2005; 竹内ほか, 2014 ; 内田, 2015 など)。 また，平野上流側では平野形成に寄与してきた河 川から優先的な地下水涵養を受けることが様々な 沖積平野や沖積扇状地で確認されており（Simmers, 1988 ; 小野寺ほか, 1996 ; 嶋田, 1998), 平 野及び扇状地上部では粘土層が存在しないあるい は断続的であることが多く, 被圧地下水が涵養さ れうる構造となっている。そのため, 被圧地下水 を含む沿岸地下水は, 水量が豊富であることから 多様な用途に利用されてきた（山本，1983; 榧根， 1989 ; 嶋田, 1998 ; 谷口, 2011 など)。

一方，現実問題として，日本やアジア各地の一 部の沿岸都市域では地下水の適切な管理が行われ ず，過剩な揚水が進んだことにより地下水の水位 低下が生じ, 海水の侵入による塩水化や地盤沈下 などの問題が引き起こされてきた (Onodera, 2011; Taniguchi, 2011; 嶋田, 2012)。例えば, 瀬戸内海沿岸の大阪平野では, 地下水の過剩揚水 が進んだ結果 1960 年代をピークとして，30 mに も及ぶ地下水位低下と $3 \mathrm{~m}$ もの積算地盤沈下に加 え, 広範囲にわたる地下水の塩水化が生じた（鶴 巻, 1992)。そのため, 地質構造の詳細把握（益 田, 2011）や地下水涵養機構の推定（中屋ほか, 2009）とともに，揚水による地下水位への影響に ついて地下水流動数值解析に基づく定量的な評価
（村岡，2005）が行われてきた。

沿岸沖積平野における持続的な地下水資源の利 用を講じていくためには，長期的な地下水の質 · 量的な観測に基づき気候変動や流域スケールでの 水需要の変動が地下水に及ぼす影響を評価してい く必要がある。例えば，気候変動の影響にともな う渴水はストックとしての水資源である地下水の 需要を増大させ, 過剩揚水による地下水位の低下 などを引き起こすことが予想される。そのため, 現在すでに揚水が過剩気味な地域では, 特に注視 が必要である。一方で, 洪水などの大出水は, 非 定常な地下水涵養を引き起こすことが, 乾燥及び 半乾燥地域に打いて明らかにされてきた（例え ば, Simmers, 1988 ; 小野寺ほか, 1996など)。し かし, 我が国のような地下水面の浅い湿潤地域で かつ地層のマトリックスが比較的均一な沖積平野 では，一般にピストン流が仮定されるため，この ような現象については従来あまり注目されてこな かった。

一方で，都市化にともなう地下水の過剩揚水に より被圧地下水の水位が $10 \mathrm{~m}$ 以上も低下した地 域では，地表付近の水を引き込む非定常な地下水 涵養が生じることも報告されている（Hayashi et al., 2009; Onodera et al., 2009 ; Shimada, 2011 ; Yamanaka et al., 2011 ; Kagabu et al., 2013など)。こ 机らは, 地下水の水理水頭やトレーサー（水の安 定同位体や地下水年代）の分布及び流動シミュ レーションによって明らかにされたものである が, 長期的な観測べースのものではないため, 変 化の過程は十分明らかにされていない。またよ り長期（数十年以上）にわたる持続的な地下水利 用のためには，気候変動にともなう非定常な地下 水涵養が地下水環境の変動に及ぼす影響を含めて 評価していく必要がある。

そこで, 本研究では政令指定都市である岡山市 が立地し，3本の一級河川からの地下水涵養が想 定される沿岸沖積平野である岡山平野を研究対象 として，8年間の現地観測を行い，定常時におけ る地下水の涵養源とその寄与率を明瞭にするとと もに，非定常な変動に注目し特に大出水時におけ 
都市化の影響を受けた沿岸沖積平野の地下水環境に及ぼす非定常な涵養機構の影響

る河川水による集中的な涵養の影響について評価 することを目的とした。

\section{II. 調査地域と方法}

\section{1. 調査地域概要}

本研究で対象とした沖積平野である岡山平野 は，岡山県南部に位置する（Fig. 1)。岡山県内に
は北部から南部に平行に流下する3本の一級河川 があり，西側から高梁川，旭川，吉井川である。 それぞれの流域最高標高は1,188 m, 1,080 m, 1,253 mであり（小野寺ほか，2018），これは岡山 県の北側に分布する大山火山（鳥取県）の標高 $1,729 \mathrm{~m}$ と比べて低い。岡山平野は，これらの主 要3河川の運搬した土砂の堆積作用によって形成 され（竹内ほか，2014），現在でも旭川と吉井川

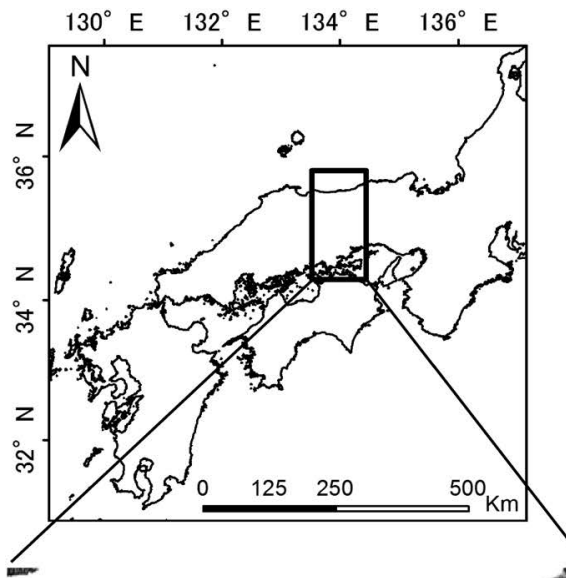

\section{Legend \\ (2) observation well}

- River water level observation station

- River water sampling point

[ Water Intake Weir
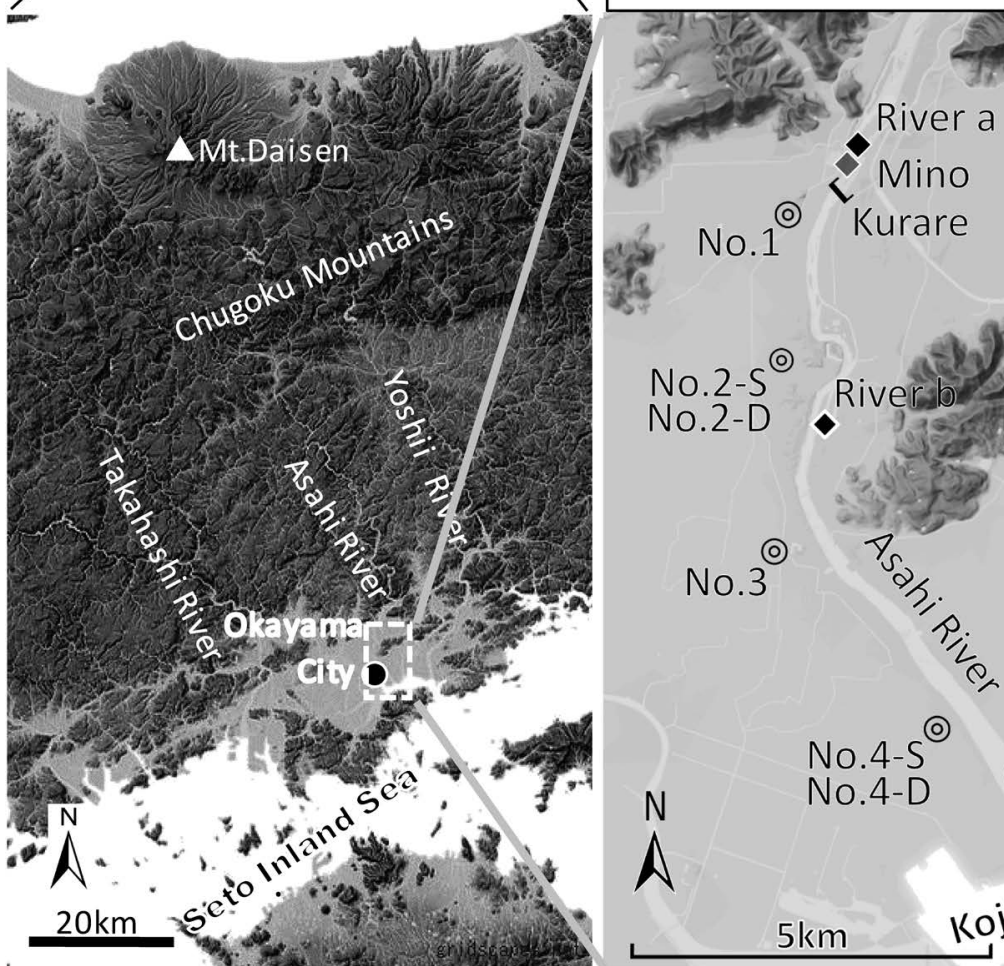

No.2-S
No.2-D River
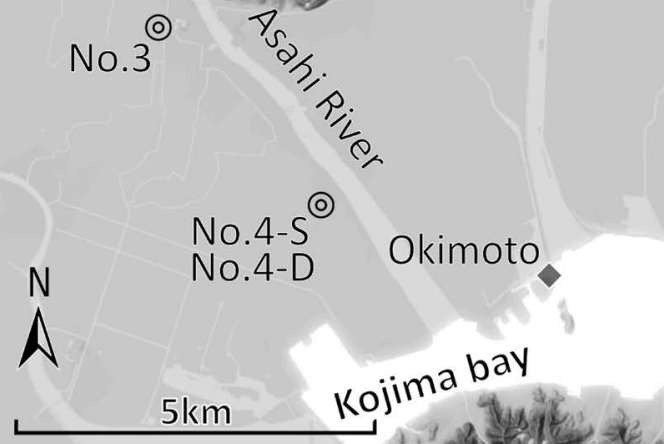

Fig. 1 Locations of observation sites. 
は平野を経由し児島湾そして瀬戸内海へと注ぐ。 岡山平野中央部に位置する旭川は岡山県北部の蒜 山高原を源流域とし，幹川流路延長は $142 \mathrm{~km}$, 流 域面積は $1,810 \mathrm{~km}^{2}$ であり, 流域の主な地質は花 崗岩や流紋岩などの火成岩及び変成岩からなる。

平野の沿岸付近（海岸から約 $5 \mathrm{~km}$ の範囲）には 埋立地や干拓農地が広がって抢り, 西川用水路に 代表される用水路網が，主要 3 河川から導水され 平野内に発達している。平野部はかつて広大な農 地であったが，近年は都市化にともない土地利用 は大きく変化し, 現在の岡山市は人口が 70 万人を 超える中核都市（政令指定都市）となっている。

ここで, Fig. 1に示したように, 観測地点は地 下水観測井が設置されている岡山市内の 4 地点 (平野上流部から沿岸部にかけてNo. 1〜No. 4) 及び河川水の水位観測を行った 2 地点（淡水河川 最下流部 $\mathrm{a}$ 及び感潮河川部 b）からなる。No. 1〜 No. 3 は概ね都心部で住宅地が密集しているが, No. 4周辺は住宅地に加え工場などが 9 割程度を 占め, 水田からなる農地も 1 割程度混在してい
る。Fig. 2 に, 竹内ほか（2014）に基づく岡山平 野に打ける4地点のボーリング調査から作成され た地質断面図を示す。最表層には人為的な盛土に 加えて現成の河川堆積物（砂砂層または汇濫原堆 積物の粘土層）が分布し，その下部に縄文海進時 に堆積した完新世粘土層 (いわゆる沖積粘土層), さらにその下部に更新世の礫層が分布する。地下 水の帯水層という視点では, Fig. 2のグレーの網 掛け部分が難透水層（沖積粘土層）であり（竹内 ほか，2014），一般には不圧地下水と被圧地下水 が表層及び深度 10〜20 m 付近に分布していると 解勫できる。難透水層は主にNo. 2 地点から下流 側に向けて徐々に層厚を増しながら連続している が，上流側のNo. 1 地点には存在していない。こ こでは, 難透水層より上部の地下水を浅部地下 水, 難透水層より下部（深度 10２0 m 付近）の地 下水を深部地下水と表記する。

\section{2. 観測井戸及び観測方法}

対象の観測井戸は，扇状地の扇頂部に相当する

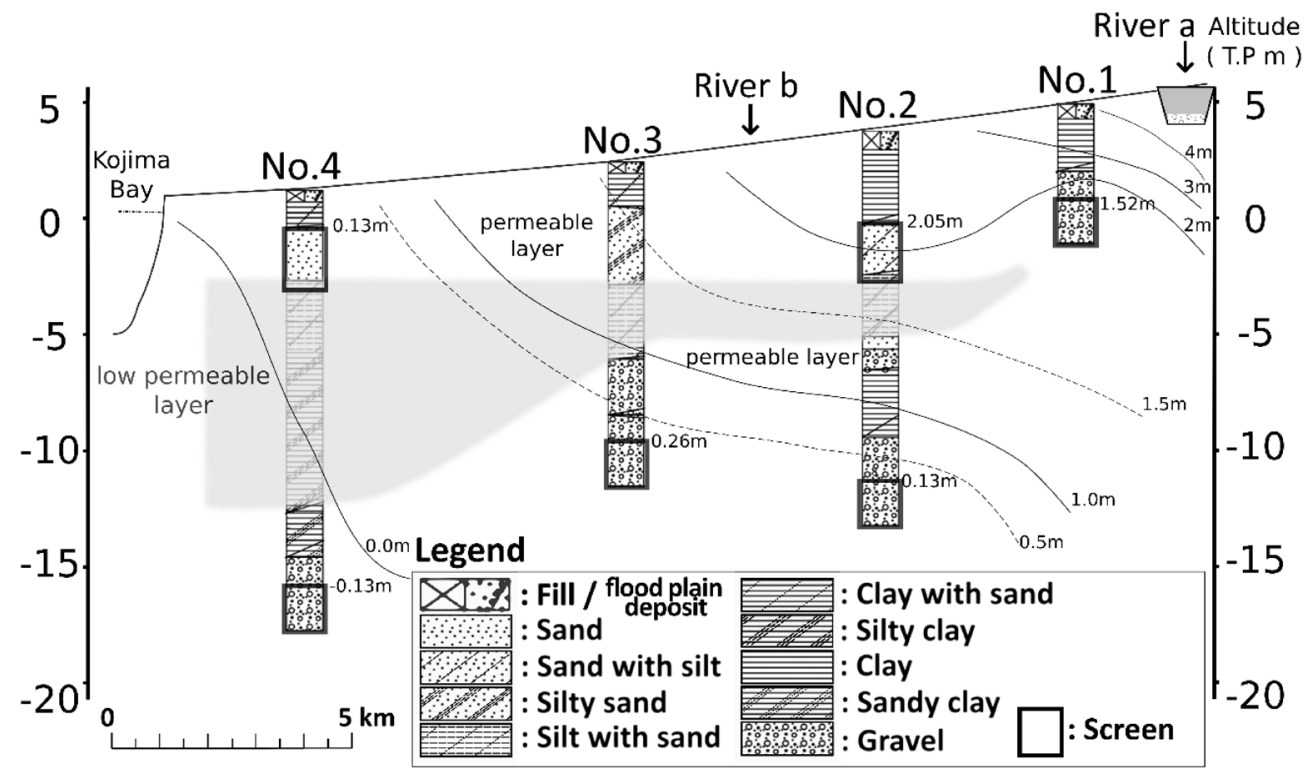

Fig. 2 Spatial distribution of hydraulic heads and the geological profile from the north mountain edge to the south bayside in Okayama alluvial plain in May in 2015.

(The numbers shown at the screen positions indicate the observed value of the hydraulic head, and the solid and dotted lines indicate the contour lines of the hydraulic head. The geological profile is based on Takeuchi et al. (2014)) 
Table 1 Specification of observation boreholes.

\begin{tabular}{lcrrrr}
\hline $\begin{array}{c}\text { Point } \\
\text { name }\end{array}$ & $\begin{array}{c}\text { Altitude } \\
(\mathrm{m})\end{array}$ & $\begin{array}{c}\text { Depth } \\
(\mathrm{m})\end{array}$ & \multicolumn{2}{c}{$\begin{array}{c}\text { Screen depth } \\
(\mathrm{m} \text {; amsl) }\end{array}$} \\
\hline No. 1 & 5.05 & 6.0 & 1.05 & to & -0.95 \\
No. 2-S & 3.88 & 6.5 & -0.12 & to & -2.62 \\
No. 2-D & 3.88 & 17.0 & -11.12 & to & -13.12 \\
No. 3 & 2.55 & 14.0 & -9.45 & to & -11.45 \\
No. 4-S & 1.33 & 4.0 & -0.17 & to & -2.67 \\
No. 4-D & 1.33 & 19.0 & -15.67 & to & -17.67 \\
\hline
\end{tabular}

平野北部から江戸時代からの干拓地である平野南 部にかけて 4 力所あり, 岡山平野中央を流れる旭 川の西岸に位置する（Fig. 1)。これらは，2008年 8月に掘削されたものである(小野寺，2009）。 掘削深度は上流部から No. 1 (御野小学校) が $6 \mathrm{~m}$, No. 2（東中山下公園）が $6.5 \mathrm{~m}$ (No. 2-S）及 び $17 \mathrm{~m}$ (No. 2-D), No. 3 (岡南小学校) が $14 \mathrm{~m}$, No. 4 (平福小学校) が $4 \mathrm{~m}$ (No. 4-S) 及び $19 \mathrm{~m}$ （No. 4-D）であり，井戸の孔径はいずれも $8 \mathrm{~cm}$ で 井戸の底から 2.0〜 $2.5 \mathrm{~m}$ の区間にスクリーンが設 けられている（Table 1, Fig. 2)。井戸掘削時の ボーリングコア試料から確認された粘土層は, 内 陸部のNo. 2では深度 $6.2 \mathrm{~m}$ から $13.2 \mathrm{~m}$ 付近にかけ て断続的に厚さ $4.7 \mathrm{~m}$ 程度, 沿岸部の No. 4 では深 度 $3.9 \mathrm{~m}$ から $15.8 \mathrm{~m}$ 付近にかけて厚さ $11.9 \mathrm{~m}$ 程度 堆積している。その下層に深部地下水が賦存して 抢り（Fig. 2)，水資源として利用されている（竹 内ほか, 2014)。

また，平野における観測井戸設置区間での旭川 の上流（River a）及び中流（River b）に扔いて河 川水の観測もあわせて行った。なお，中流（River b) は潮汐の影響を受ける場所である。各井戸 には水位及び水温の計測ロガー（HOBO-U20 ウォーターレベルロガー, Onset）を設置し，大 気圧観測用の同ロガーもNo. 3 井戸孔内に設置し， 連続観測を行った。なお，旭川の該当区間には国 土交通省の水位観測所（三野）があり，そのデー タも参照した。

採水及び現地観測は2008年8月から継続して 1 年間に 2 回以上の頻度で行い，本研究では 2008 年から 2016年の間に採水した 16 回の試料を扱う
こととした。採水は，観測井戸孔内に溜まってい る水（古い水）を採水器もしくは水中ポンプに よって揚水したのちに，スクリーン付近の深度の 水を揚水して行った。採水時には, 電気伝導度 (EC), $\mathrm{pH}$, 溶存酸素濃度 (DO), 酸化還元電位 (ORP) をそそれぞれポータブル電気伝導率計 (CM-21P, TOADKK 及びB-173, 堀場製作所), $\mathrm{pH}$ 計（HM-20P, TOADKK），DO計（HQ30d，

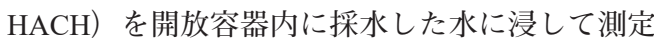
し，ORP計（RM-20P, TOADKK）は電極を密閉 容器に採水した水に封入して測定した。

な捄, 分析用の水試料は, 孔径 $0.2 \mu \mathrm{m}$ のメン ブレンフィルターを用いて採水直後にろ過し，ポ リプロピレン $(\mathrm{PP})$ 製スピッッ管に密閉のうえ 持ち帰り分析まで冷凍保管した。保管した試料は 実験室にて酸素・水素安定同位体比 $\left(\delta^{18} \mathrm{O}\right.$ 及び $\delta$ D) をWS-CRDS 法 (L2120-i, Picarro) (Gupta et al., 2009）によって定量分析した。また，2015年5 月 1 日に打ける採水試料は, 重炭酸イオン $\left(\mathrm{HCO}_{3}^{-}\right)$ を硫酸滴定法にて定量し, 主要陽イオン $\left(\mathrm{Na}^{+}\right.$, $\left.\mathrm{K}^{+}, \mathrm{Mg}^{2+}, \mathrm{Ca}^{2+}\right)$ につてはICP-AES (Optima3000, PerkinElmer) により，主要陰イオン $\left(\mathrm{Cl}^{-}, \mathrm{NO}_{3}^{-}, \mathrm{SO}_{4}^{2-}\right)$ についてはイオンクロマト グラフ（LC-VP, SHIMADZU）で定量した。

\section{III. 結果}

\section{1. 地下水の化学組成及び水理水頭分布}

Fig. 2に各観測井戸に打いて 2015年 5月に計測さ れた，基準面を海水面とする水理水頭の鉛直分布 及び竹内ほか（2014）に基づく地質断面図を示す。 水理水頭の上流部はRiver aの河川水位である $5 \mathrm{~m}$ とした。地下水位の季節変化がみられてもこの空 間分布の傾向はほぼ変わらないため, ここでは代 表的な 1 時期のみについて示した。この結果から， 地下水は全体的に上流側から下流側に向かって流 動しているが，上流側の等值線の幅がより狭く，動 水公配が急であることがわかる。水理水頭の差は, River a から No. 1 間が最も大きく 5.5 mある。一方 で，No.1から No. 2-S間ではほとんど差がないのに 

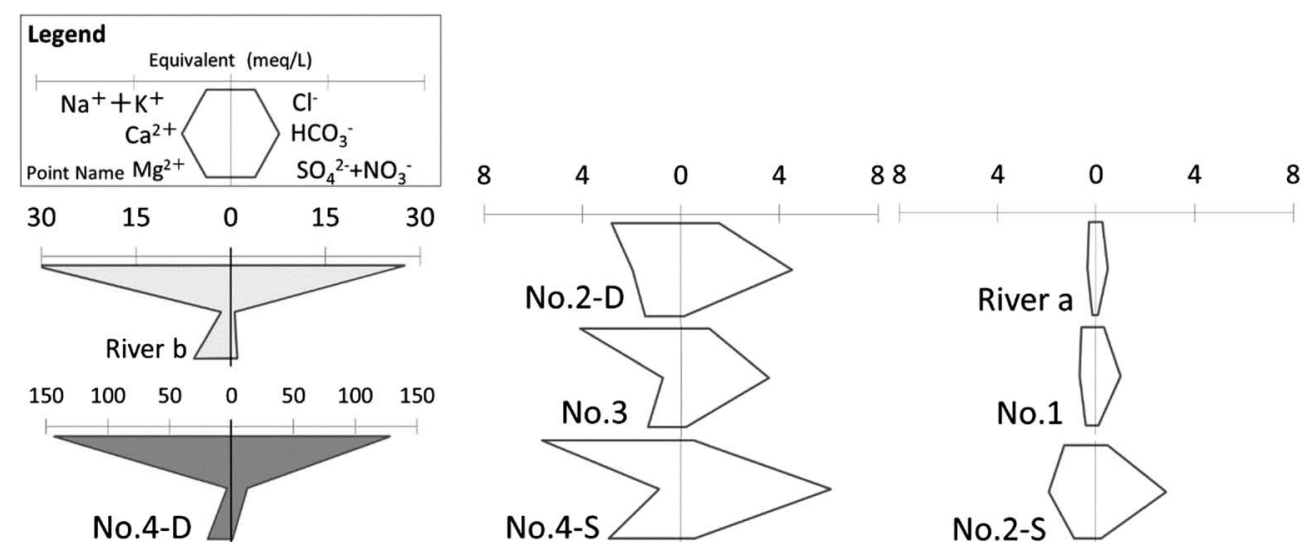

Fig. 3 Hexa-diagrams of groundwater and river water samples in May 2015 for the same transect with Fig. 2.

対して，No. 1 から No. 2-D間で約一 $1.4 \mathrm{~m}$ と大き。 それに対して，下流側では等值線の幅が広く，す なわち動水勾配が小さく，水理水頭の差はNo. 2-D から No. 4-Dで約一 0.3 mである。

また，Fig. 3 に2015年 5 月における地下水及び 河川水の主要無機イオン成分組成を示す。浅部及 び深部地下水ともに, No. 1 から No. 4八流動方向 に沿って総無機イオン濃度が増加する傾向を示 す。成分組成は $\mathrm{Ca}-\mathrm{HCO}_{3}$ 型, $\mathrm{Na}-\mathrm{HCO}_{3}$ 型, $\mathrm{Na}-$ $\mathrm{Cl}$ 型の3パターンに分けられる。 $\mathrm{Ca}-\mathrm{HCO}_{3}$ 型を示 すのは河川水の River a と地下水の No. 1, No. 2-S である。これらは上流側の河川水と深度 $5 \mathrm{~m}$ 程度 の浅部地下水である。一方で $\mathrm{Na}-\mathrm{HCO}_{3}$ 型を示し たのはNo. 2-D，No. 3，No. 4-Sである。 $\mathrm{Na-Cl}$ 型 はRiver b (感潮域), No. 4-Dであり, $\mathrm{Cl}^{-}$濃度は No. 4-Dの地下水に打いて河川水の5倍以上の高 濃度を示した。なお，これらの傾向は既往研究 （松見ほか，2010）と同様である。

\section{2. 酸素・水素安定同位体比の分布}

Fig. 4 に水試料の $\delta^{18} \mathrm{O}$ と $\delta \mathrm{D}$ の関係を示す。困中 の点線は全球の天水線 $\left(\delta \mathrm{D}=8 \times \delta^{18} \mathrm{O}+10\right)$ を示 す。また，実線は標準海水 $\left(\delta^{18} \mathrm{O}: 0 \%, \delta \mathrm{D}: 0 \% \mathrm{o}\right)$ と岡山市の降水の平均值 $\left(\delta^{18} \mathrm{O}:-8.45 \%, \delta \mathrm{D}\right.$ : $-56.2 \%$ ） との混合線を示す。な找，降水の平均 值は岡山大学津島キャンパス（No.1から北西約 $1 \mathrm{~km})$ で異なる2つの時期に実施された研究結果

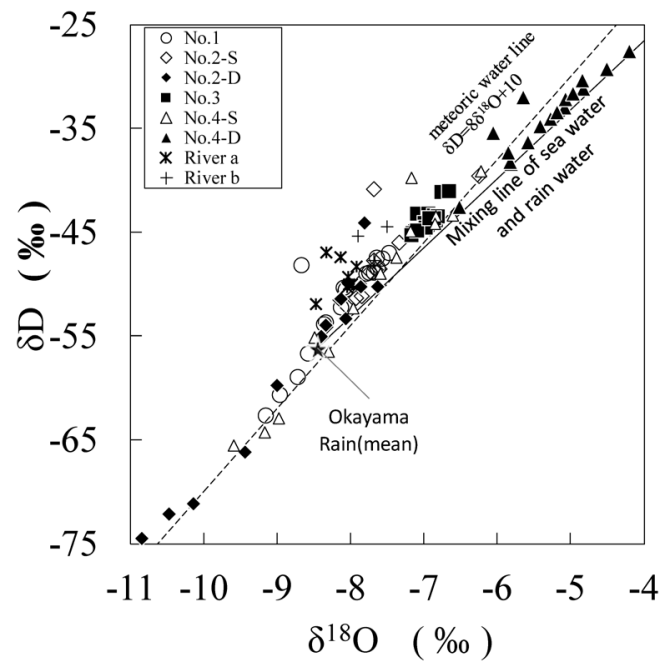

Fig. 4 Relationship between $\delta^{18} \mathrm{O}$ and $\delta \mathrm{D}$ of collected water samples.

（一柳・田上（2016）による2012年12月から 2014年 1 月までの年間加重平均值 $\left(\delta^{18} \mathrm{O}:-8.8 \%\right.$, $\delta \mathrm{D}:-59.3 \%$ ） と山本ほか（1993）による 1991年 6 月から 1 年間の加重平均值 $\left(\delta^{18} \mathrm{O}:-8.1 \%, \delta \mathrm{D}\right.$ : $-53 \% 0)$ ) を平均したものである。本研究で採取 された水試料は，概ね天水線付近に分布する。こ れは，本沖積平野で採取された水試料のほとんど が降水由来であることを示す。

地下水と河川水を比較すると, 河川水のほうが 天水線より上側に位置し, River a (上流側) が River b（下流側）より同位体比が低い。地下水は 
都市化の影響を受けた沿岸沖積平野の地下水環境に及ぼす非定常な涵養機構の影響

No. 4-Dの同位体比が最も高く，感潮域である River bよりも高い。一方で，低い同位体比に着 目するとNo. 2-Dの值が降水や上流側の浅部地下 水であるNo.1の水より低い時期がある。

\section{3. 地下水の水理水頭, EC 及び安定同位体比の長} 期変化

Fig. 5aに2008年6月〜2016年6月までの岡山市 における日降水量（気象庁，2016）, 旭川三野観
測所における河川水位（国土交通省，2016）及び 地下水の水理水頭の変化を示す。ここでは化学組 成と同位体比の変動から特徵的な 3 箇所 (No. 2-S, No. 2-D, No. 4-D）を選定し示した。前述のよ うに，No. 2-S は化学組成が Ca- $\mathrm{HCO}_{3}$ 型，No. 2-D は $\mathrm{Na}-\mathrm{HCO}_{3}$ 型，No. 4-D $\mathrm{Na}-\mathrm{Cl}$ 型である。な お，河川水位及び地下水の水理水頭については, 潮汐の影響を除去するため 24 時間移動平均值で 示している。地下水の水理水頭は概ね梅雨期から

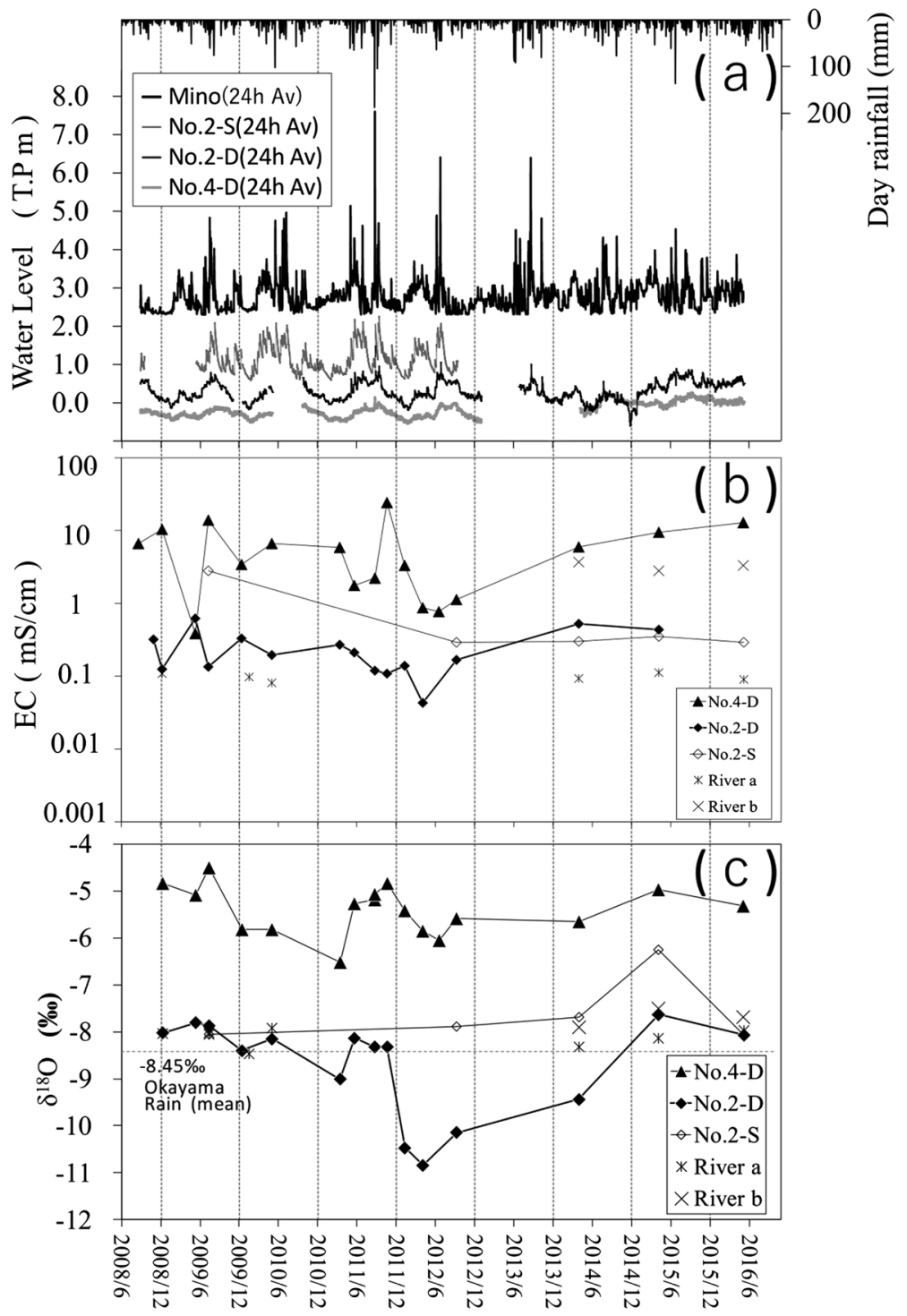

Fig. 5 Fluctuations in 24-hour average of water levels in river and groundwater and daily precipitation (a), and seasonal variation in $\mathrm{EC}(\mathrm{b})$ and $\delta^{18} \mathrm{O}(\mathrm{c})$ of river and groundwater. 
台風期（6月～9月）にかけて高く，冬季から初 夏（12月～5月）にかけて低下する傾向を示す。 No. 2-Sの季節変動幅は 1.6 m, No. 2-Dは1.4 m, No. 4-Dは0.6 mで, No. 2-Sが最も変動が大きい。そ れに対して, 河川の変動幅は $5.2 \mathrm{~m}$ (平水時と 2011年9月の最大水位の差）と地下水に比べて顕 著に大きい。

Fig. 5bに河川水（River a, River b）及び地下水 (No. 2-S, No. 2-D, No. 4-D）の電気伝導度 (EC) を, Fig. $5 \mathrm{c} に \delta^{18} \mathrm{O}$ の変動をそれぞれ示す。地下水 の ECの変動には, どの地点においても特に明瞭 な周期性はみられない。ただし，No. 2-Dでは 2012年 4 月に最低值を示し，それ以外の期間は上 流河川水（River a）よりも高い值を取っている。

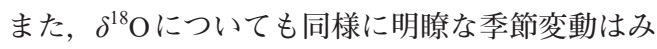
られないが，No. 2-Sの同位体比は比較的変動が 小さく平均的な值で推移し, No. 2-Dは変動が大 きく相対的に低い值を示し, No. 4-Dは変動が大 きく相対的に高い值を示す。特にNo. 2-Dでは 2012年 4 月から約 2 年にわたり顕著に低い值を示 している。これについてはFig. 4でも言及したよ うに，降水の平均值と比べても明瞭に低い值であ る。一方でNo. 4-Dにおいては，2011年5月に最 低值を示し，次に2012年7月にも若干低い值を示 している。また，No.4-Dにおいては全体的にNo. 2-D と比較してEC及び $\delta^{18} \mathrm{O}$ が高く, ECについて は2009年7月や 2011 年 11 月に $10 \mathrm{mS} / \mathrm{cm}$ 以上の高 い值を示すとともに， $\delta^{18} \mathrm{O}$ もこの時に高い值を示 している。

\section{N. 考察}

\section{1. 定常時における沖積平野の地下水涵養一流動 状況}

Fig. 2 及びFig. 5 で示したように，No. 2-Dより 海側の深部地下水の水理水頭はほぼゼロからマイ ナスの值となっていた。一般に, 沖積平野におけ る自然状態の被圧地下水は涵養域（平野上端付 近）の地表面標高に近い水理水頭を保持し自噴す ることがある（Freeze and Cherry, 1978など）こと
を考虑すれば，本論中における岡山平野の深部地 下水の場合は $2 \mathrm{~m}$ から $5 \mathrm{~m}$ 程度あっても良いと推 定される。しかし，それに比べると低く，人為的 な揚水などにともなう水位低下の影響を受けてい ることが明らかになった。

また，各観測井戸における同位体比は変動して おり，その変動幅やパターンはそれぞれ異なって いた（Fig. 4, 5)。まず，定常時の地下水涵養特性 を把握するために，対象期間中の各観測井戸にお ける同位体比の平均值を算出し, 地下水の涵養源 が河川水, 降水, 海水の3成分からなると仮定
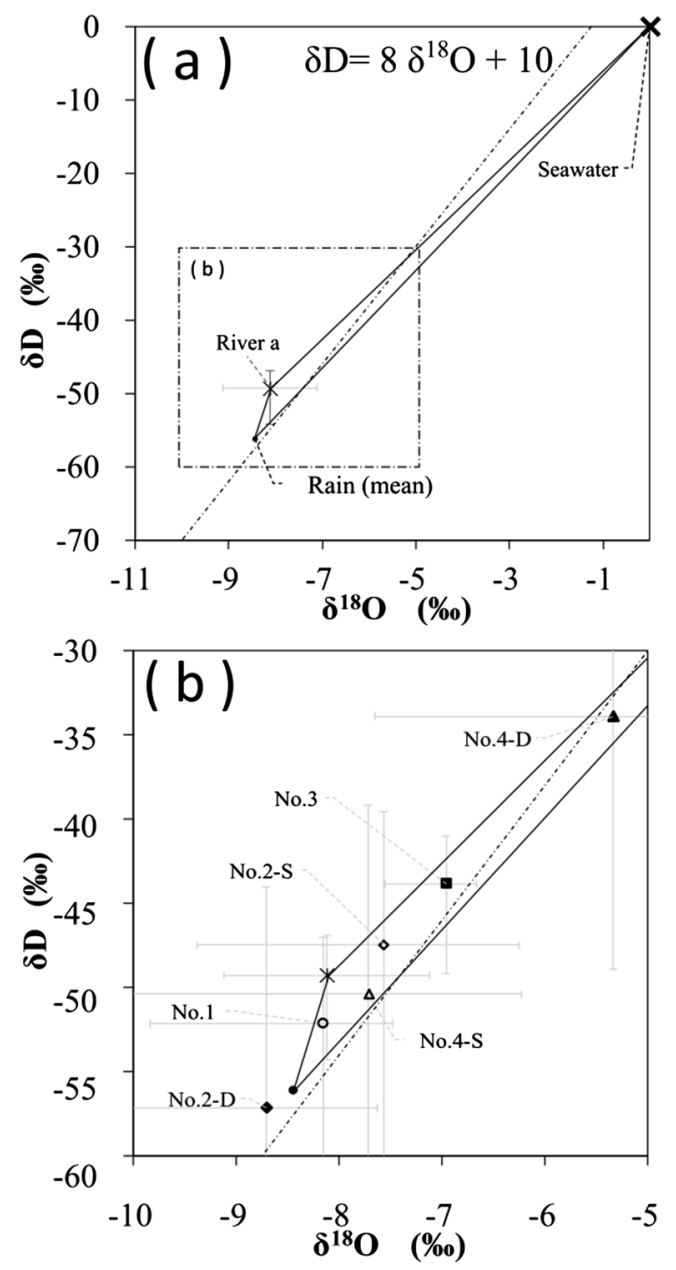

Fig. 6 Distribution of end-member composed of rainwater, river water and seawater (a) and average values of collected groundwater samples (b) in the $\delta^{18} \mathrm{O}$ and $\delta \mathrm{D}$ diagram. 
Table 2 Average EC and stable isotopic ratios of groundwater samples and estimated mixing ratios of seawater, river water, and precipitation.

\begin{tabular}{|c|c|c|c|c|c|c|c|c|}
\hline \multirow{2}{*}{ Point name } & \multicolumn{3}{|c|}{ Average } & \multicolumn{2}{|c|}{$\begin{array}{l}\text { Estimated mixing ratio } \\
\text { from EC }\end{array}$} & \multicolumn{3}{|c|}{$\begin{array}{l}\text { Estimated mixing ratio } \\
\text { from isotope }\end{array}$} \\
\hline & $\begin{array}{c}\mathrm{EC} \\
(\mathrm{mS} / \mathrm{cm})\end{array}$ & $\begin{array}{l}\delta^{18} \mathrm{O} \\
(\%)\end{array}$ & $\begin{array}{l}\delta \mathrm{D} \\
(\%)\end{array}$ & Seawater & $\begin{array}{l}\text { Fresh } \\
\text { water }\end{array}$ & Seawater & $\begin{array}{l}\text { River } \\
\text { water }\end{array}$ & $\begin{array}{l}\text { Precipita- } \\
\quad \text { tion }\end{array}$ \\
\hline No. 1 & 0.16 & -8.2 & -52 & $<1 \%$ & $>99 \%$ & $0 \%$ & $51 \%$ & $49 \%$ \\
\hline No. 2-S & 0.23 & -7.6 & -48 & $<1 \%$ & $>99 \%$ & $7 \%$ & $66 \%$ & $26 \%$ \\
\hline No. 2-D & 0.54 & -8.9 & -59 & $1 \%$ & $99 \%$ & - & - & - \\
\hline No. 3 & 0.59 & -7.0 & -44 & $1 \%$ & $99 \%$ & $15 \%$ & $60 \%$ & $25 \%$ \\
\hline No. 4-S & 0.58 & -7.7 & -50 & $1 \%$ & $99 \%$ & $8 \%$ & $17 \%$ & $75 \%$ \\
\hline No. 4-D & 6.42 & -5.3 & -34 & $13 \%$ & $87 \%$ & $36 \%$ & $29 \%$ & $35 \%$ \\
\hline
\end{tabular}

し，エンドメンバー法を用いて各々の比率を求め ることとした。岡山平野の降水の加重平均值 （一柳・田上（2016）と山本ほか（1993）の平均 值)，上流河川水 (River a) の平均值及び海水 (標準海水) の $\delta^{18} \mathrm{O}$ と $\delta$ D 関係を Fig. 6aに示し, Fig. 6bに各観測井戸の平均値（図中のエラーバー は最大值と最小值を示す）を拡大して示す。これ らの結果から，No. 2-Dを除く観測井戸の平均值 は3つのエンドメンバーを結んだ三角形内に内包 され，これにより推定された 3 成分の混合割合を Table 2に示す。また，ECに基づく淡水と海水の 混合率もあわせて示している。なお，No. 4-Dに 打ける $\mathrm{EC}(\mathrm{mS} / \mathrm{cm})$ と $\mathrm{Cl}^{-}$濃度 $(\mathrm{mg} / \mathrm{L})$ の相関 式は $\left[\mathrm{Cl}^{-}\right]=591 \times[\mathrm{EC}]-534\left(\mathrm{R}^{2}=0.98\right)$ であ り， $\mathrm{EC}$ の上昇は概ね $\mathrm{Cl}^{-}$の上昇を示していると みられる。No. 1, No. 2-S, No. 3 は降水と海水と の混合線よりも河川水と海水との混合線側に寄っ て打り，河川水の混合率が 5 割程度と比較的高 かった。なおNo. 2-Sでは海水の寄与がわずかに 見積もられた。No.2のすぐ東側の旭川は感潮河 川区間であり，大潮の満潮時などに地下水中に塩 分がわずかに侵入していることが示唆される。ま た，都心部であるため，家庭排水などの人為的影 響の可能性も無視できない。対照的に，No. 4-S では降水の混合率が約 $75 \%$ と高く見積もられた。 No. 4-Sの水理水頭值は標高 $0.13 \mathrm{~m}$ （Fig. 2）であ るのに対し，直近の旭川は感潮域にあたり，平均 水位は $0 \mathrm{~m}$ 程度である。干満にともない周辺地下 水と河川水の短期的な交流は考えられるが，扇状
地の平野上流域とは異なり，河川水が地下水に定 常的に流入しているとは考えにくい。No.4があ るエリアは江戸時代初期に干拓された土地で平坦 であり，観測井が設置された学校の周辺には住宅 や水田が分布する。そのため，降水が校庭や周囲 の田面から浅部地下水に浸透し，そのまま河川に 流出するという極めてローカルな流動を示唆して いるものと考えられる。一方，No. 4-D は海水の 混合率が約 $36 \%$ と高く推定され，河川水の割合 が約 $29 \%$ で残りが降水であった。ここでは水理 水頭值がマイナス (-0.13 m: Fig. 2) となってお り河川水や海水の定常的な侵入を示していた。

\section{2. 深部地下水における $\mathrm{EC}$ 及び $\delta^{18} \mathrm{O}$ の長期的な 変動特性}

Fig. 5で示したようにNo. 2-D及びNo. 4-Dでは $\mathrm{EC} 及 ひ ゙ \delta^{18} \mathrm{O}$ が長期的にみて比較的大きな変動を 示した。ただし，前節で述べたと打り，No. 2-Dに ついては $\delta^{18} \mathrm{O}$ と $\delta \mathrm{D}$ から想定される 3 種類のエン ドメンバー (河川水，降水及び海水) では説明が できなかった。ここでは，Fig. 7にNo. 2-D及び No. 4-DのECと $\delta^{18} \mathrm{O}$ との関係を示す。Fig. 7aにお けるNo. 2-Dの変化傾向をみると, ECが約 $0.2 \mathrm{mS} / \mathrm{cm}$ から $0 \mathrm{mS} / \mathrm{cm}$ の僅かな間では ECの低下 とともに $\delta^{18} \mathrm{O}$ が急に低下しているのに対して, $\mathrm{EC}$ が約 $0.2 \mathrm{mS} / \mathrm{cm}$ 以上では，ECの上昇に対して $\delta^{18} \mathrm{O}$ は緩やかに上昇するもしくはほぼ横ばいであ る。この結果から，図中に示したような 3 種類の エンドメンバー $(\mathrm{A}, \mathrm{B}, \mathrm{C})$ による影響が示唆さ 
れる。具体的には， $\mathrm{EC}$ 及び $\delta^{18} \mathrm{O}$ がともに低い $\mathrm{A}$, $\mathrm{EC}$ が約 $0.12 \mathrm{mS} / \mathrm{cm}$ で ${ }^{18} \mathrm{O}$ が約一 $8.0 \%$ である $\mathrm{B}$, $\mathrm{EC}$ が約 $0.7 \mathrm{mS} / \mathrm{cm}$ で $\delta^{18} \mathrm{O}$ がー $7.5 \%$ 付近のCであ る。図中では, AとBの混合領域のプロットは白 抜きで，BとCの混合領域のプロットは黒塗りで
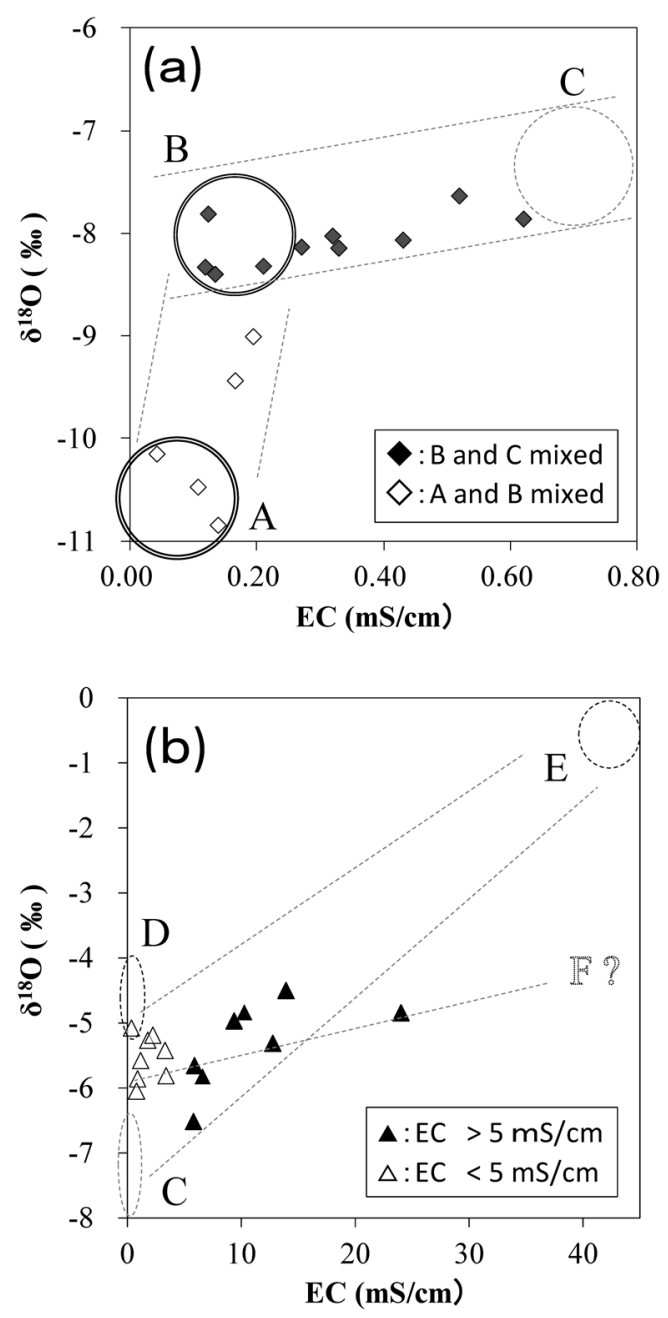

Fig. 7 Relationship between EC and $\delta^{18} \mathrm{O}$ of groundwater at No. 2-D (a) and No. 4-D (b).
示した。ここで，Cは前節での議論（Fig. 6, Table 2) からわずかに塩水が混合した深部地下水（No. 2-D, No. 3, No. 4-Dにつながるような水と推測) でBは河川水が混合した浅部地下水（No. 2-S の ような水と推測）であると考えられる。一方で, $\mathrm{A} の \delta^{18} \mathrm{O}$ は調査期間中の河川水や降水の加重平均 值よりも低い水ということになる。

この $\mathrm{EC}$ 及び $\delta^{18} \mathrm{O}$ がともに低い $\mathrm{A}$ の水の由来に ついて考察するため, Fig. 5 に打いて, No. 2-Dの $\delta^{18} \mathrm{O}$ が特に低い值を示した時期（2012年1月から 9月）の中心期2012年6月から約 10 ヶ月前（300日 前）に発生した2011年9月の台風 12 号による大 雨に注目した。この台風12号に打いて, 旭川流 域の上流での 2 日雨量は $300 \mathrm{~mm}$ を超過し, 流域 平均では，9月1日18時から4日21時までに $206 \mathrm{~mm}$ の雨量を記録した（国土交通省岡山河川 事務所，2011）。またこの時，河川水位は観測期 間中の 8 年間で最も上昇した。一般に，降水の同 位体比は台風の大雨時に低くなることが知られて いる(藪崎・田瀬，2004など）。本研究では，残 念ながらこの台風期間中の旭川の同位体比変化は 取得できていないが，岡山平野に隣接する倉敷市 高梁川に打いて採水された河川水の分析結果を Table 3に示す。2018年7月の豪雨時及び同年 9 月 の台風2 1 号による高水位時及び通常の平水位時 の同位体比を比較したが，洪水時に顕著に同位体 比が低下していることが明らかである。すなわ ち，旭川と同規模の高梁川では，大規模な降雨時 に降水量効果などが作用して河川水の同位体比が 低下していたことが確認できた。したがって, 旭 川でも同様の現象が起きていたとすれば，増水時 にECと $\delta^{18} \mathrm{O}$ がともに低下した河川水をエンドメ ンバー Aと仮定でき，その水が地下水へ浸透し

Table $3 \mathrm{EC}$ and $\delta^{18} \mathrm{O}$ of river water samples in the low and high flow periods in Takahashi River.

\begin{tabular}{cccrl}
\hline Name & Date & $\begin{array}{c}\mathrm{EC} \\
(\mathrm{mS} / \mathrm{cm})\end{array}$ & $\begin{array}{r}\delta^{18} \mathrm{O} \\
(\%)\end{array}$ & Note \\
\hline Takahashi River_Sakazu area & $2018 / 7 / 2$ & 0.130 & -8.1 & low flow \\
Takahashi River_Sakazu area & $2018 / 7 / 9$ & 0.109 & -10.7 & high flow (after 2018 Japan flood) \\
Takahashi River_Sakazu area & $2018 / 8 / 7$ & 0.152 & -9.1 & low flow \\
Takahashi River_Sakazu area & $2018 / 9 / 10$ & 0.107 & -10.5 & high flow (after Typhoon No. 21) \\
\hline
\end{tabular}


都市化の影響を受けた沿岸沖積平野の地下水環境に及ぼす非定常な涵養機構の影響

Table 4 EC, Na, and $\mathrm{Ca}$ concentrations and $\mathrm{Na} / \mathrm{Ca}$ ratios in No. 2-D and River a.

\begin{tabular}{lccccc}
\hline \multicolumn{1}{c}{ Name } & Date & $\begin{array}{c}\mathrm{EC} \\
(\mathrm{mS} / \mathrm{cm})\end{array}$ & $\begin{array}{c}\mathrm{Na} \\
(\mathrm{meq} / \mathrm{L})\end{array}$ & $\begin{array}{c}\mathrm{Ca} \\
(\mathrm{meq} / \mathrm{L})\end{array}$ & $\mathrm{Na} / \mathrm{Ca}$ \\
\hline $\begin{array}{l}\text { No.2-D } \\
\text { (low isotope ratio) }\end{array}$ & $2012 / 9 / 24$ & 0.043 & 0.20 & 0.11 & 1.8 \\
No.2-D & $2015 / 5 / 1$ & 0.520 & 3.74 & 0.74 & 5.1 \\
River a & $2015 / 5 / 1$ & 0.111 & 0.27 & 0.37 & 0.7 \\
\hline
\end{tabular}

ていたと考えることができるだろう。加えて， Table 4 に平水時の河川 (River a) 及びNo. 2-Dの $\mathrm{EC}$ 及び化学組成として $\mathrm{Na} / \mathrm{Ca}$ 比を示す。陸水は 総じて $\mathrm{Ca}^{2+}$ が優先し, 海水は $\mathrm{Na}^{+}$が圧倒的に高 い傾向を示すことから, $\mathrm{Na} / \mathrm{Ca}$ （ここでは meq/L での比）は陸水系か海水系のどちらが優先するか を明確に示すことができる（Drever, 1988）。この ことから $\mathrm{Na} / \mathrm{Ca}$ 比をとることにより，定量的に変 化を見ることができると想定される。同位体比が 顕著に低下していた2012年9月のNo. 2-Dでは平 水時の河川水よりも低い $\mathrm{EC}$ の值が観測され，化 学組成についても， $\mathrm{Na} / \mathrm{Ca}$ 比が通常時（2015年 5 月） 5 以上であるのに対して，2以下となってお り，河川水の值に近くなる傾向を示した。以上の 結果も, Aのエンドメンバーが洪水時の河川水で ある可能性を支持していると考えられる。なお， 同位体比が低下する台風以外の他の要因につい て，高度効果や深度が $400 \mathrm{~m}$ 以上深く古い水（山 田ほか，2006）の混入が考えられる。小野寺ほか （2018）によると，岡山県付近における降水の高 度効果は, 日本海側と瀬戸内側で $\mathrm{d}$ 值にばらつき が見られるものの， $\delta^{18} \mathrm{O}$ がー9.6\% 程度の沢水が 示されており，高度が $100 \mathrm{~m}$ 上昇するに従って約 $0.2 \%$ 低下するとみられる。しかし，このような 高度効果を受けた水が選択的にNo. 2-Dに到達す るとは考えにくい。深度が深く古い水は水期の寒 冷気候下で涵養された低同位体比の水が仮定され るが， d值が異なり現在の天水線付近から外れる とともにECが高くなることが考えられ，このエ ンドメンバーAの説明としては考えにくい。

次に, Fig. 7bにおけるNo. 4-Dの変化傾向をみ

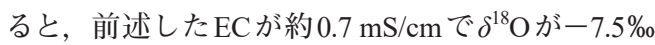
付近のC (塩分がわずかに混合した深部地下水)

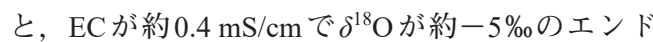
メンバー Dと， EC及び $\delta^{18} \mathrm{O}$ とに高いエンドメ ンバー Eの 3 成分混合で概ね説明ができる。この うち，Dについては，前述の結果（Fig. 6, Table 2）から原位置で浸透した田面水などが想定され る。一般に水田に打ける田面水は蒸発濃縮を受け ることにより同位体比が高くなることが知られて おり（例えば，涌井・山中，2006），Dはそれに 該当すると考えられる。田面水の同位体比の特徵 として, 天水線より右にプロットされ, $\mathrm{d}$ 值が低 くなることが示されている。No. 4-Dにおいて， 田面水と同様の特徵をしめしているが，海水成分 の混入が考えられる水の同位体比も同様の特徴を 示すと考えられる。現状において d 值が低くなっ ている要因が田面水であるか海水であるか明睹な 判断はできなかった。また，Eについては海水が 想定される。罒中でECが $5 \mathrm{mS} / \mathrm{cm}$ 以下を白抜き で，5 mS/cm以上を黒塗りで示した。ECの結果 からは, 白塗りのプロットはDの田面水の寄与が 大きくなっているのに対して，黒塗りのプロット はEの海水成分の寄与が大きくなることが読み取 れる。また，ばらつきはあるものの ECが低く $\delta^{18} \mathrm{O}$ がー7.5\%o周辺のC (深部地下水) にD（田面 水) が主体となって混合したエンドメンバーと海 水との2成分混合のように変動していた。一方で C-Eの混合線の下に外れるプロット（2011年 11 月，期間中最大洪水から 2 ケ月後）がみられ， $\mathrm{EC}$ が高く $(30 \sim 40 \mathrm{mS} / \mathrm{cm}), \delta^{18} \mathrm{O}$ がー5〜ー4\%o程 度で推移する罒のF付近（比較的滞留時間の長い 水と想定される）にもエンドメンバーを見いだせ る可能性が残る。

ここで，長期的にみて大きな変動がみられた No. 2-D及びNo. 4-Dについて，その要因について 
友澤 $\cdot$ 小野寺 $\cdot$ 齋藤 $\cdot$ 竹内 $\cdot$ 北岡
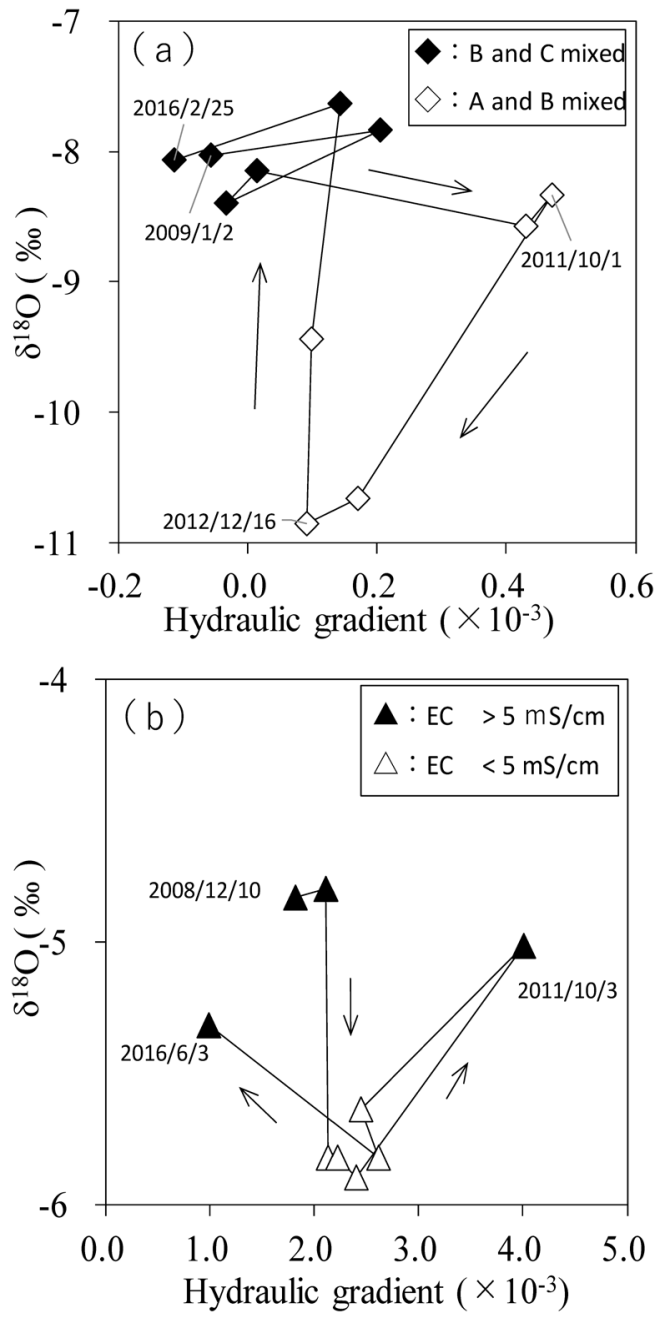

Fig. 8 Relationship between hydraulic gradient and $\delta^{18} \mathrm{O}$ of groundwater at No. 2-D (a) and No. 4-D (b) .

確認するため，河川から地下水への動水勾配と $\delta$ ${ }^{18} \mathrm{O}$ の関係を確認する（Fig. 8)。より長期的な傾 向をみるため，同位体比は約半年おきのデータ間 隔とし，動水勾配は，採水時から 1 力月前までの 期間における最大值を示した日の日平均值を示し た。なお，動水勾配を算出する際に使用した河川 水位は，No. 2-Dに対しては国土交通省三野観測 所，No. 4-Dに対しては同沖元観測所の值とした (位置はFig. 1に示す)。この付近の旭川は感潮区 間であり，その水位は児島湾沿岸の沖元観測所の 日平均水位と同等であると仮定した。No. 2-D と
河川との距離については，三野観測所から下流 $800 \mathrm{~m}$ に位置するクラレ取水堰からの約 $2.1 \mathrm{~km}$ と した。堰付近まで河床標高及び水位の变化はあま りなく，涵養可能エリアと推定できる。No. 4-D は直近の旭川河道までの距離 $230 \mathrm{~m}$ とした。 それでれFig. 7での白抜き及び黒塗りのプロッ 卜を同じ条件で示し，6力月ごとの時系列の関係 を線で結んで矢印で示している。Fig. 8aのNo. 2-Dでは，比較的動水勾配が小さい $\left(0.2 \times 10^{-3}\right.$ 以下）時期は $\delta^{18} \mathrm{O}$ がー8.4〜-7.6\% で安定してい た（黒塗りマーク）のに対して，動水勾配が観測 期間中最大值を示した時期の半年後から $\delta^{18} \mathrm{O}$ が 急激に低下したことが確認できた。それから 1 年 程度はFig. 7で示したAとBの混合領域（白抜き マークで表示）にとどまっていたことがわかる。 これらの結果から，期間中最大の動水勾配を引き 起こしたのは台風通過時の大出水であり, その結 果 $\mathrm{EC}$ 及び $\delta^{18} \mathrm{O}$ が低下した洪水由来の河川水に よって地下水が非定常に涵養されたことが示唆さ れた。

一方で, Fig. 8bのNo. 4-Dでは, 動水勾配が $2.0 \sim 3.0 \times 10^{-3}$ と平均的で安定している時期には $\delta^{18} \mathrm{O}$ が低く変動も小さく, ECも5 mS/cm以下の 塩水化の程度が小さい状況（白抜きのマークで表 示）が保持されたのに対して，動水勾配が平均值 より小さい時期（揚水量が少ないなど地下水位が 上昇した時期 : 2014年以降）や大きい時期（洪 水などにともない河川水位が上昇した時期）には 同位体比が上昇するとともに EC も $5 \mathrm{mS} / \mathrm{cm}$ 以上 に上昇していた。現段階では，これらの要因に関 しては未解決であるが，今後さらに解析を進めて いく必要がある。

\section{3. 平野中央都心部における深部地下水への非定 常な涵養機構}

結果（林章）に扔いて Fig. 5で示したように， No. 2-D は $\delta^{18} \mathrm{O}$ の変動幅が大きくかつ2012年4月 に $-10.8 \%$ と顕著に低い值（岡山平野の降水の加 重平均值- $8.5 \%$ p平水時の河川水の值 $-8.1 \%$ と比 べても低い）を示し，元の值に戻るのに 24 カ月 
以上を要していた。そのため全期間の平均值は Fig. 6に打ける3成分 (降雨, 河川水, 海水) 混 合の枠には当てまらなかった。また，前節で考察 したように，これには洪水時の河川水による非定 常な涵養が影響していることが示唆された。以上 の結果から，2011年9月に発生した台風12号に よって 8 年間の観測期間で最も顕著な大出水が生 じ (Fig. 5a), この増水時に河川水の同位体比が 大きく低下し，その水が深部地下水を涵養したこ とが推測される。そこで，2011年の大雨による 河川水位上昇の深部地下水への影響を検討するた め, No. 2-Dへの河川による涵養域を推定する。 河川水が地下へ浸透するためには, 難透水層がな く，主に砂礫層など透水性のよい地質で構成され ているエリアが必要である。No. 2 地点の孔口標 高は $3.88 \mathrm{~m}$ であり，地下の標高 $-3 \mathrm{~m}$ 以深に難透 水層（縄文海進時に堆積した粘土質層）が数 $\mathrm{m}$ の厚さで存在することから (Fig. 2), この地点で の鉛直方向への透水性は良好とはいえない。一般 に，いわゆる沖積粘土層は地表標高の上昇ととも に内陸に行くほど薄くなる。No. 1及び周囲の ボーリング情報（国土交通省，2008; 岡山県, 2016）によれば，標高約 $5 \mathrm{~m}$ の表層から標高約 $2 \mathrm{~m}$ まで表土及び河川由来の粘土層が分布する が，それ以深から $-15 \mathrm{~m}$ 程度までには礫層があ り，No. 2-Dの深部地下水につながっていると考 えられる。No. 1 地点直近河道の平均河床高は標 高 $1 \mathrm{~m}$ 程度であり（国土交通省，2007)，No.1で 若干見られた粘土層の基底部標高より低い。その ため, No. 1 地点付近の現河道や旧河道上では粘 土層は存在しないと考えられる。すなわち, No. 1 近くの三野観測所付近において深部地下水を構 成する礫層への浸透が生じ, No. 2-Dの涵養域と なっていることが考察できる。そこで，三野観測 所下流の堰から No. 2-D間に打いて深部地下水へ の水平方向の流動を想定し, 動水勾配, 透水係数 を算出することとした。

まず，No. 2-Dに到達する地下水の平均間隙流 速 $v$ 及び到達時間 $T$ を見積もる。平均間隙流速 $v$ は，(1）式のダルシー則から得られるダルシー流
速と間隙率 $n$ によって，(2) 式のように求められ る(藤縄，2010）。

$$
\begin{aligned}
& q=-K \cdot d h / d s \\
& v=q / n
\end{aligned}
$$

ここで, $K$ は飽和透水係数 $(\mathrm{cm} / \mathrm{s}), d h d s$ は動水 勾配である。堰から No. 2-D までの直線距離は約 $2.1 \mathrm{~km}$ であり, 動水勾配は平均 $1.20 \times 10^{-3}$ (2011 年 9 月から 2012 年 9 月までの間の 1 年間), 最大時 $2.88 \times 10^{-3}$ （2011年9月4日，河川水位 $7.52 \mathrm{~m}, \mathrm{No}$. 2-D水位 $1.47 \mathrm{~m})$, であった。同様に, No. 2 地点 におけるNo. 2-S とNo. 2-Dの間（深度差 $8 \mathrm{~m}$ ）の 鉛直方向の動水勾配は最大時 0.18 (2011 年 9 月 20 日, No. 2-S 水位 $2.18 \mathrm{~m}$, No. 2-D水位 $0.76 \mathrm{~m}$ ), 最 小時 0.025 (2012年8月 23 日, No. 2-S 水位 $0.72 \mathrm{~m}$, No. 2-D水位 $0.52 \mathrm{~m}$ ）であった。さらに, 透水係 数は水平方向を砂層での輸送として $1.0 \times 10^{0} \mathrm{~cm} / \mathrm{s}$ (藤縄，2010; 丸山ほか，2015), No. 2-S からの鉛 直方向を砂混りシルト (層厚 $2.65 \mathrm{~m}$ ), 砂 (層厚 $0.55 \mathrm{~m}$ ), 砂磁（層厚 $0.90 \mathrm{~m}$ ), 砂質粘土（層厚 $2.9 \mathrm{~m}$ ), 礫（層厚 $1.00 \mathrm{~m}$ ）での通過ということ で，それぞれ $1.0 \times 10^{-3} \mathrm{~cm} / \mathrm{s}, 1.0 \times 10^{-2} \mathrm{~cm} / \mathrm{s}, 1.0 \times$ $10^{-1} \mathrm{~cm} / \mathrm{s}, 1.0 \times 10^{-6} \mathrm{~cm} / \mathrm{s}, 1.0 \times 10^{-0} \mathrm{~cm} / \mathrm{s}$, と し, 次式から求めた（Freeze and Cherry, 1978)。

$$
K z=\frac{d}{\sum_{i=1}^{n} d i / K i}
$$

ここで, $K z$ は鉛直方向の平均透水係数 $(\mathrm{cm} / \mathrm{s})$, $d$ はスクリーン中央深度 $(\mathrm{m}), d i$ は各層厚 $(\mathrm{m})$, $K i$ は各透水係数 $(\mathrm{cm} / \mathrm{s})$ である。計算の結果, 鉛 直方向の飽和透水係数は $2.8 \times 10^{-6} \mathrm{~cm} / \mathrm{s}$ となった。

以上の結果, 最大の動水勾配と透水係数を使用 し, 水平方向と鉛直方向のダルシー流速を比較す ると約 $2.49 \mathrm{~m} /$ day と $4.29 \times 10^{-5} \mathrm{~m} /$ day となり水平方 向のほうが鉛直方向より有意に大きかった。ここ で，間隙率を丸山ほか（2015）によってトレーサー 輸送速度から推定された 0.2 程度とすれば，横方向 の最大の平均間隙流速は約 $12.4 \mathrm{~m} /$ day となる。さ らに, No. 1付近の河道から浸透した水がNo. 2-D 
に到達する時間は，169日と見積もられる。同様に 1 年間の動水勾配の平均值で計算した場合, 到達 時間は405日と見積もられる。これらの推定結果か ら， $\delta^{18} \mathrm{O}$ の最低值を示した時期が 2011 年 9 月の台 風12号による大雨からの遅れ時間である約 300 日 は，ほぼ妥当な範囲であることが確認できた。

以上の結果をまとめると，台風 12 号の記録的 な大雨により河川水位が上昇し, 通常より大きな 動水勾配が生じ，大雨を含む河川水が多く地下水 へ浸透したと考えられる。また，その当時の河川 水は降水量効果などにより同位体比が低い水で あったと考えられ，それらによる集中的な涵養に ともない, 河川に比較的近い地点の深部地下水で 同位体比の低い水が一時期出現したものと考えら れる。このようなイベント的な地下水涵養は, 乾 燥地域ではこれまでも確認されてきた（Simmers, 1988 ； 小野寺ほか，1996など）が，長期的な観 測の結果，湿潤地域に扎いても都市化にともない 地下水圧低下がみられ地表水との動水勾配が大き い沿岸沖積平野では，十分起こりうることが確認 できた。これは，沿岸沖積平野に打ける長期的な 地下水管理においても重要である。

\section{V. まとめ}

本研究では，都市化した沿岸沖積平野である岡 山平野を対象とした 8 年間の観測結果に基づき, 定常的な地下水涵養一流動状況を明らかにすると ともに, 深部地下水に対する非定常な地下水涵養 の影響について推定を行った。その結果, 以下の ことが明らかになった。

1）深部地下水の水理水頭はほぼゼロからマイナ スの值を示し，人為的な揚水などにともなう水 位低下が示唆された。また，定常時における地 下水の涵養源は，沖積平野上流側では河川水の 寄与が $50 \%$ 以上を占め $\mathrm{Ca}^{2+}$ 及び $\mathrm{HCO}_{3}^{-}$が主成分 となっているのに対し，下流側では原位置の降 水及び海水の寄与が大部分を占め $\mathrm{Na}^{+}$及び $\mathrm{Cl}^{-}$ が主成分となっていることが明らかになった。

2） 2008 年 6 月～2016年 6 月までの地下水の酸素
安定同位体比の変動において, 平野中央部の深 部地下水では2012年1月から約 2 年にわたり顕 著に低い值を示し, 沿岸の深部地下水では 2011年11月に電気伝導度で最高值を示した。 2011 年 9 月に観測期間中最大の洪水（台風 12 号）があり，いずれも水理水頭が低下した深部 地下水に対して動水勾配が最大となったこと で, 洪水時の河川水による優先的な地下水涵養 及び海水の侵入にともなう影響が示唆された。

3）平野中央部の被圧地下水に対する河川水の涵 養速度をダルシー則に基づき洪水後 1 年間の動 水勾配で推定したところ, 洪水時の河川水が 169〜405日で深部地下水に到達すると見積もら れた。この時間は，2011年9月の最大出水時と 深部地下水中に打ける $\delta^{18} \mathrm{O}$ の最低值が出現した 時期との遅れ時間である約 300 日の範囲内にあ り，台風にともなう大雨によって同位体比が低 下した河川水による非定常な涵養が支持された。 以上のような非定常な地下水涵養は, 都市化に ともなう地下水位低下がみられる沿岸沖積平野 では十分起こりうると考えられ，持続可能な地 下水利用を講じていくうえでは, 非定常な地下 水涵養現象も考慮して評価していく必要がある。

\section{謝辞}

本研究は，科学研究費補助金基盤研究（基盤研 究A）「瀬戸内海流域wqから海洋への陸域地下起 源物質の不均一・非定常な流出機構の定量的評 価」（研究課題番号：18201007; 代表者 : 福岡正 人）及び農林水産省先端技術を活用した農林水産 技術高度化事業「備讃地域陸海域の水・栄養塩動 態解明と農業への再利用技術の開発」(課題番 号：1947；研究総括者：吉川省子）より観測井戸 掘削などの支援を頂いた。長期の試料採取・デー タ集積にあたっては, 歴代の広島大学小野寺研究 室及び岡山理科大学北岡研究室の方々にご尽力頂 きまた，観測井戸を設置させて頂いている各小 学校など施設関係者の方々に扔かれましても長年 に渡りご協力いただき，打礼申し上げます。 
都市化の影響を受けた沿岸沖積平野の地下水環境に及ぼす非定常な涵養機構の影響

\section{文献}

一柳錦平・田上雅浩（2016）日本全域に打ける降 水の安定同位体比一2013年集中観測の結果よ り一. 日本水文科学会誌，46(2)，123-138.

内田洋平 (2015) 筑後・佐賀平野の地盤沈下と地 下水管理の現状．地下水学会誌，57，19-27.

岡山県（2016）扣かやま全県統合型GIS（地盤情 報)．http://www.gis.pref.okayama.jp/pref-okayama/Portal（2019.10.15閲覧）

小野寺真一 (2009) II 備讃地域陸海域の水・栄 養塩動態解明 2 備讃地域陸域からの負荷量推 定技術 4）地下水流出負荷 - 干潟浄化用推定 技術. 備讃地域陸海域の水・栄養塩動態解明と 農業への再利用技術の開発，先端技術を活用し た農林水産技術高度化事業平成 19～21年度 研 究成果報告書 課題番号1947（研究総括者： 吉川省子)，38-47.

小野寺真一 · 近藤昭彦 ·佐藤芳徳 - 林正貴 - 新藤 静夫・松本栄次・池田宏（1996）東アフリカ, タンザニアの半乾燥地域に打ける地中水循環. 八イドロロジー (日本水文科学会誌)，26，7586.

小野寺真一・宮越昭暢（2010）特集号「地下水流 動系と熱/物質輸送」刊行にあたって. 地下水 学会誌，52，333-334.

小野寺真一・齋藤光代 - 北岡豪一（2018）瀬戸内 海流域の水環境一里水一. 吉備人出版, $266 \mathrm{p}$. 榧根勇（1989）河川と地下水. 地学雑誌，98, $42-52$.

気象庁（2016）過去の気象データ・ダウンロー ド. http://www.data.jma.go.jp/gmd/risk/obsdl/ (2016.7.1閲覧)

国土交通省（2007）旭川河川概要. http://www. mlit.go.jp/river/toukei_chousa/kasen/jiten/nihon kawa/87076/87076-1.html（2016.7.1 閲覧）

国土交通省（2008）国土地盤情報検索サイト. http://www.kunijiban.pwri.go.jp/jp/index.html (2019.10.15閲覧)

国土交通省（2016）国土交通省川の防災情報. https://www.river.go.jp/portal/\#80（2016.7.1閲覧） 国土交通省岡山河川事務所（2011）【旭川】平成23 年9月3日～ 5 日『台風 12 号による出水』. http:// www.cgr.mlit.go.jp/okakawa/ (2016.7.1 閲覧) 齋藤庸・ 三宅紀治（2003）関東平野南西域の地下 水収支に関する検討. 日本水文科学会誌，33, 197-214.

嶋田純（1998）「地下水涵養と流出」I． 扇状地に 打ける地下水涵養と流出. 日本水文科学会誌, 28, 63-69.

嶋田純（2012）モンスーンアジア地域における可 能地下水涵養量を考慮した地下水資源管理．日 本水文科学会誌，42(2)，33-42.

竹内徹 · 北岡豪一 - 山口一裕 - 小野寺真一 （2014）閉鎖性海域沿岸沖積平野における完新 世粘性土層の形成過程について一岡山平野の 例一. 日本水文科学会誌，44(3)，161-177.

谷口真人（2011）地下水流動一モンスーンアジア の資源と循環一，共立出版， $294 \mathrm{p}$.

鶴巻道二（1992）大阪平野に打ける被圧地下水の 塩水化について。地下水技術，34(10)，37-50. 中屋眞司 · 三田村宗樹 · 益田晴恵 · 上杉健司 · 本 舘佑介・日下部実・飯田智之・村岡浩爾 （2009）環境同位体と水質より推定される大阪 盆地の地下水の涵養源と流動特性. 地下水学会 誌， 51 (1)， 15-41.

林武司 · 内田洋平 · 安原正也 · 丸井敦尚 - 佐倉保 夫 ·宮越昭暢（2003）水質・同位体組成からみ た関東平野の地下水流動。日本水文科学会誌,

33, $125-136$.

林武司・宮越昭暢・安原正也（2007）大都市圈の 発達に伴う地下水環境の変化と課題. 日本水文 科学会誌，37，271-285.

藤縄克之（2010）環境地下水学. 共立出版, $354 \mathrm{p}$. 益田晴恵（2011）都市の水資源と地下水の未来. 京都大学学術出版会, $249 \mathrm{p}$.

松見悠世・山口一裕·北岡豪一（2010）岡山平野 地下水に打ける水質の特徵と流動系. 第 32 回 陸水物理研究会広島大会講演予稿集, P16. 丸山豊 · 小野寺真一 · 北岡豪一 (2015) 河川近傍 
の “みずみち” 状湧水に打ける水温変動を利用 した地下水フラックスの推定. 地下水学会誌, 57, 207-219.

三宅紀治・齋藤庸（2003）東京，埼玉の沖積低地 を主とした被圧地下水流動について。日本水文 科学会誌, 33, 185-196.

村岡浩爾（2005）沿岸都市域における地下水総合 管理のための地下水涵養モデルの構築. 平成 14 年度 平成 16 年度科学研究費補助金（基盤 研究 (B) (1)) 研究成果報告書, $126 \mathrm{p}$.

藪崎志穂 - 田瀬則雄（2004）台風到来時の降水の 酸素・水素安定同位体比の変動特性. 筑波大学 陸域環境研究センター報告，5，29-39.

山田誠 ·平川丈志 · 松田亮 · 山口一裕 · 北岡豪 一・日下部実（2006）温泉水の水素と酸素の安 定同位体比から推定される深部花崗岩中の水の 由来. 日本水文科学会誌, 36 (4), 205-218.

山本荘毅（1983）新版 地下水調査法. 古今書 院, $490 \mathrm{p}$.

山本雅弘 · 北村俊博 · 赤木誠司 ·古川孝文 $\cdot$ 日下 部実（1993）岡山県下の天水の水素及び酸素同 位体比. 地下水学会誌, 35(2), 107-112.

涌井久司・山中勤（2006）安定同位体組成からみ た那須扇状地扇央部に打ける地下水涵養源とそ の地域性. 地下水学会誌, 48(4), 263-277.

Drever, J. I. (1988) The Geochemistry of Natural Waters. Prentice Hall, New Jersey, 437 p.

Freeze, A. R. and Cherry, J. A. (1978) Groundwater. Prentice Hall, New Jersey, $604 \mathrm{p}$.

Gupta, P., Noone, D., Galewsky, J., Sweeney, C. and Vaughn, B. H. (2009) Demonstration of high-precision continuous measurements of water vapor isotopologues in laboratory and remote field deployments using wavelength-scanned cavity ring-down spectroscopy (WS-CRDS) technology. Rapid Communications in Mass Spectrometry, 23, 2534-2542.

Hayashi, T., Tokunaga, T., Aichi, M., Shimada, J. and Taniguchi, M. (2009) Effects of human activities and urbanization on groundwater environments: An example from the aquifer system of Tokyo and the surrounding area. Science of the Total Environment, 407, 3165-3172.

Kagabu, M., Shimada, J., Delinom, R., Nakamura, T. and Taniguchi, M. (2013) Groundwater age rejuvenation caused by excessive urban pumping in Jakarta area, Indonesia. Hydrological Processes, 27, 2591-2604.

Onodera, S., Saito, M., Sawano, M., Hosono, T., Taniguchi, M., Shimada, J., Umezawa, Y., Lubis, R. F., Buapeng, S. and Delinom, R. (2009) Erratum to "Effects of intensive urbanization on the intrusion of shallow groundwater into deep groundwater: Examples from Bangkok and Jakarta." Science of the Total Environment, 407, 3209-3217.

Onodera, S. (2011) Subsurface pollution in Asian megacities. In Groundwater and Subsurface Environments, Taniguchi, M. (Ed.), Springer, 159-184.

Shimada, J. (2011) Chemical and physical evidences in the groundwater aquifer caused by over-pumping of groundwater and their countermeasures in the major Asian coastal cities. In Groundwater and Subsurface Environment, Taniguchi, M. (Ed.), Springer, 289-309.

Simmers, I. (Ed.) (1988) Estimation of Natural Groundwater Recharge. NATO ASI Series C, vol. 222, Springer, $528 \mathrm{p}$.

Taniguchi, M. (Ed.) (2011) Groundwater and Subsurface Environments. Springer, 310 p.

Yamanaka, T., Mikita, M., Lorphensri, O., Shimada, J., Kagabu, M., Ikawa, R., Nakamura, T. and Tsujimura, M. (2011) Anthropogenic changes in a confined groundwater flow system in the Bangkok Basin, Thailand, part II: How much water has been renewed? Hydrological Processes, 25, 2734-2741.

原稿受付：2021年2月 20 日 原稿受理：2021年4月 15 日

この論文に詨する「討論」を2022年2月28日 まで受け付けます。 


\title{
都市化の影響を受けた沿岸沖積平野の地下水環境に及ぼす 非定常な涵養機構の影響
}

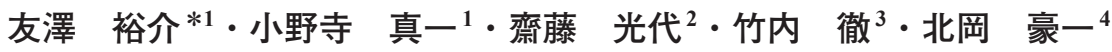 \\ 要 旨
}

本研究では，瀬戸内海沿岸の岡山平野に扎ける地下水位，一般水質，酸素・水 素安定同位体比の 8 年間に及ぶ観測結果に基づき，特に大出水時に打ける河川水 による非定常な涵養機構が地下水環境に及ぼす影響について明らかにすることを 目的とした。

平野に打ける深部地下水（深度 10～20 m）の水理水頭はほぼゼロからマイナ スの值を示し，人為的な揚水などにともなう水位低下が示唆された。また，定常 時に打ける地下水の涵養源は沖積平野上流側では主に河川水で, 下流側では降水 及び海水と推定された。一方，観測期間中最大の洪水後に，平野中央部の深部地 下水では酸素安定同位体比 $\left(\delta^{18} \mathrm{O}\right)$ が約 2 年間にわたり顕著に低い值を示し，沿 岸の深部地下水では電気伝導度が最高值を示した。これらの結果から，平野中央 部では水理水頭の低下した深部地下水に対して洪水時に上昇した河川水位との動 水勾配が期間中で最大となり，河川水が優先的に地下水を涵養したこと，また下 流側では感潮河川からの海水の侵入の影響が示唆された。さらに, 洪水時におけ る河川水の平野中央部深部地下水への到達時間は, 洪水後 1 年間の動水勾配で推 定すると 169〜405日と見積もられ，洪水時から深部地下水に打ける $\delta^{18} \mathrm{O}$ の最低 值が出現するまでの時間（約 300 日）の範囲内にあり，洪水時の河川水による非 定常な地下水涵養が支持された。

キーワード : 沖積平野, 非定常, 地下水涵養, 酸素 - 水素安定同位体比 